\title{
Evaluation of Using Hibiscus sabdariffa Calyces in the Production of Rotenesse Smoked Beef (Se'i)
}

\author{
Malelak GEM, Sipahelut GM, Jelantik IGN \\ Department of Animal Science, Nusa Cendana University \\ Jl. Adisucipto Penfui, Kupang 85001, East Nusa Tenggara, Indonesia \\ geminimalelak@yahoo.com.au
}

\begin{abstract}
Aims of this experiment were to evaluate the use of Hibiscus sabdariffa extract on the production of $s e^{\prime} i$ (Rotenesse smoked beef). A completely randomized design was used in this study. Treatments include: $\mathrm{Po}=s^{\prime} i$ was without Hibiscus sabdariffa extract as control, $\mathrm{P}_{1}=\mathrm{se}^{\prime} i$ given Hibiscus sabdariffa extract $1 \%(\mathrm{w} / \mathrm{v}) ; \mathrm{P}_{2}=\mathrm{se}$ ' $i$ was given Hibiscus sabdariffa extract $2 \%$ $(\mathrm{w} / \mathrm{v}) ; \mathrm{P}_{3}=\mathrm{se}$ ' $i$ was given Hibiscus sabdariffa extract $3 \%(\mathrm{w} / \mathrm{v}) ; \mathrm{P}_{4}=\mathrm{se}$ ' $i$ was given Hibiscus sabdariffa extract $4 \%(\mathrm{w} / \mathrm{v})$; and $\mathrm{P}_{5}=$ se' $i$ was given Hibiscus sabdariffa extract $5 \%(\mathrm{w} / \mathrm{v})$, each treatment had three replication. Variables for this experiment include: flavour, color, taste, tenderness, pH, total plate count, Coliform, Escherichia coli, Salmonella and Staphylococcus aureus. Result showed that Hibiscus sabdariffa extract was not significantly affected the flavour, color, tenderness and $\mathrm{pH}$. However, Hibiscus sabdariffa extract enhanced the taste of $s e$ ' $i(\mathrm{P}<0.05)$. Also, the extract significantly reduced both total plate count and Staphylococcus aureus numbers $(\mathrm{P}<0.05)$. As a matter of fact, Coliform, Escherichia coli and Salmonella were not detected in all se' $i$. In conclusion Hibricus sabdariffa was able to enhanched the taste of se' $i$ and inhibit the growth of bacteria.
\end{abstract}

Key Words: Se'i, Hibiscus sabdariffa, Organoleptics, Bacterial

\section{INTRODUCTION}

$S e^{\prime} i$ is a dry-cured smoked meat product which is usually made from ruminant meat or pork. At present, se'i has been produced as a home industry in Kupang and the products have been distributed to many culinary markets in many parts of Indonesia.

$S e^{\prime} i$ is not completely dry but it still contains $40-60 \%$ water, consequently, it is easy to be contaminated by bacteria. Some of the contaminating bacterial in the product may cause food borne illness, shorten shelf-life of food and finally could lead to economic loss for food producers.

Using of natural ingredients to inhibit bacterial growth in food, including meat products, is an interesting option to solve the problem. One of the natural ingredients that usually used as antibacterial agent is Hibiscus sabdariffa or roselle.

It has been reported that roselle extract could inhibit Salmonella typhimurium, Escherichia coli, Listeria monocytogenes, Staphylococcus aureus and Bacillus cereus both in ground beef and apple juice (Chao \& Yin 2009). Roselle calyces contain antibacterial compounds such as: organic acids, phenolic acids, alkaloids and athocyanins (Christian \& Jackson 2009); ascorbic acids and flavonoids (Morales-Cabrera et al. 2013); anthocyanins, flavonoids and polyphenols (Lin et al. 2007). In meat products, roselle calyces could reduce lipid oxidation of kavurma (Bozkurt \& Belibagl 2009) and sucuk (Karabacak \& Bozkurt 2008). In addition, many beneficial properties have been obtained from roselle calyces in food, drink and also medicine industry throughout the world. Thus, the roselle plant is now widely grown in numerous countries in the world. However, in West Timor, Indonesia, Roselle (Hibiscus sabdariffa) just grows naturally in agricultural land and home yard. The utilization of this plant in West Timor is only for spices in kitchen. The objective 
of the study was to investigate the effects of Hibiscus sabdariffa calyces extract on the organoleptic aspects and microbial activity of $s e^{\prime} i$.

\section{MATERIAL AND METHODS}

\section{Materials}

A total of $30 \mathrm{~kg}$ of beef from butt and rump of Bali cattle was obtained from a meat shop in Kupang. Salt (2\%) and Kalium nitrate $\left(\mathrm{KNO}_{3}\right)$ (300 $\mathrm{mg}$ of kg-1) were added. Hibiscus sabdariffa calyces were obtained from Naimata village, Kupang, East Nusa Tenggara Province, Indonesia. Schleichera oleosa wood and leaf was obtained around Kupang regency.

\section{Hibiscus sabdariffa extract}

The calyces were dried in oven at $60^{\circ} \mathrm{C}$ for 3 days, then blended with Philips blender to abtain the mass. To obtain $1 \%, 2 \%, 3 \%$ and $4 \%(\mathrm{w} / \mathrm{v})$ of roselle extract, each of $1,2,3$ and $4 \mathrm{~g}$ of roselle mass poured into volumetric glass and added distilled water up to 100 $\mathrm{ml}$, stirred at $60^{\circ} \mathrm{C}$ for 5 minutes and filtered with Whatman (No. 41) (Karabacak \& Bozkurt 2008) with modification.

\section{Treatment and $s e$ 'i processing}

Completely randomized design (CRD) with 6 treatments was assigned for this experiment. Beef was trimmed off the excessive fat then sliced in rope-shape (lalolak), mixed well with salt and Kalium nitrat. The mixture was split into six batches namely: Po $=s e^{\prime} i$ without rossele/ as control; $\mathrm{P}_{1}=$ Rossele extract $1 \%(\mathrm{w} / \mathrm{v}) ; \mathrm{P}_{2}=$ Rossele extract $2 \%$ $(\mathrm{w} / \mathrm{v}) ; \mathrm{P}_{3}=$ Rossele extract 3\% (w/v); $\mathrm{P}_{4}=$ Rossele extract $4 \%(\mathrm{w} / \mathrm{v}) ; \mathrm{P}_{5}=$ Rossele extract $5 \%(\mathrm{w} / \mathrm{v})$, mixed well and marinated for 12 hours.

After marinating, the sliced-meat was arranged in frame, covered with Schleichera oleosa leaf and then smoked using Schleichera oleosa wood for 45-60 minutes or until well done. A distance between the meat and the wood was approximately $45 \mathrm{~cm}$.

\section{Parameter measured}

\section{Organoleptic test}

The organoleptic test was carried out using hedonic scale. Twenty five untrained panelists from Animal Science Faculty students were chosen for sensory analysis (flavour, color, taste and tenderness). To examine the flavour $30 \mathrm{~g}$ of samples were sliced, put into small glass jars and allowed to stand for several hours (Bensink et al. 1973). On opening the jars the panelists immediately sniffed the flavour and was asked to give "score 1" if no flavour to "score 5" very strong flavour. The color score was as follows: $5=$ very bright red color; 4 = bright red color (specific se'i color), $3=$ dark red, $2=$ moderately dark red, 1 $=$ light red. Whereas, the taste score was $5=$ like very much, $4=$ like moderately, $3=$ like slight, 2 = dislike moderately and $1=$ dislike very much. The tenderness score was $5=$ very tender, $4=$ moderately tender, $3=$ slight tender, $2=$ tough, $1=$ very tough. For each treatment, each penelist had three pieces of $s e^{\prime} i$ to be evaluated. An average of the three measurements to calculate mean score for each of the color, flavour, taste and tenderness of se' $i$ sample. 


\section{Determination of $\mathrm{pH}$}

Se'i sample was about 10 grams was chopped and mixed well with $10 \mathrm{ml}$ of distilled water then the probe of $\mathrm{pH}$ was placed into the dilution and the $\mathrm{pH}$ of sample was read. Determination of $\mathrm{pH}$ value was measured using a Hanna digital $\mathrm{pH}$-meter at ambient temperature. Each sample was measured 3 times.

\section{Bacterial analyses}

Ten grams finely chop of se' $i$ from each treatment were homogenized with $100 \mathrm{ml}$ sterile $0.1 \%$ peptone water containing $0.85 \% \mathrm{NaCL}$ and $1 \%$ Tween 80 as emulsifier, at 40 $45^{\circ} \mathrm{C}$ for 2 minutes in a Stomacher $400 \mathrm{Lab}$ Blender. Ten $\mathrm{ml}$ of the preceding was diluted with $0.1 \%$ sterile peptone water. Total plate count were enumerated in standard plate count agar (Oxoid agar) after incubation at $35^{\circ} \mathrm{C}$ for $48 \mathrm{~h}$, then all colonies on plates were counted (Harrigan \& McCance 1976; Elliot et al. 1978). Coliform counts were determined using violet red bile agar (Oxoid CM 107) after incubation at $37^{\circ} \mathrm{C}$ for $24 \mathrm{~h}$. Coliform colonies were identified as round, red to pink, $0.5-2 \mathrm{~mm}$ in diameter, surrounded with a red to pink halo. Escherichia coli were isolated by using EC broth and EMB agar (Harrigan \& McCance 1976). For Salmonella sp, a $50 \mathrm{~g}$ of homogenisate was transferred to a sterile Erlenmeyer flask with $200 \mathrm{ml}$ buffered peptone water (Oxoid CM 509) and incubated at $37^{\circ} \mathrm{C}$ for 24 hours. After that a combination of bismuth sulphite agar (Oxoid, CM 201), modified brilliant green agar (Oxoid, CM 329) and hectoen enteric agar (Oxoid, CM 419) was used for selective plating. Presumptive salmonella colonies selected from each of selective plate were confirmed by using API 20 E identification system as described by the manufacturer (Bio Meri eux, Basingstoke, UK). (Harrigan \& McCance 1976; Elliot et al. 1978). S. aureus counts predried Baird-Parker agar (Oxoid, CM 275), incubated at $37^{\circ} \mathrm{C}$ for 24 to 48 hours. Typical colonies were counted. Colonies were selected from agar surfaces to be examined under microscope for gram strain and tested for catalase reaction, and also coagulate activity by using rabbit plasma with EDTA (Elliot et al. 1978).

\section{Statistical analysis}

The data of flavour, color, taste and tenderness were analyzed using non parametric, Kruskas-Wallis test. Mann-Whitney test was used to test for difference between means (significance $\mathrm{P}<0.05$; highly significant was $\mathrm{P}<0.01$ ). $\mathrm{pH}$ and bacterial data were analysed with analysis of variance (ANOVA). Least Significant Differences test was used to determine the differences among means (significantly different was $\mathrm{P}<0.05$; highly significant was $\mathrm{P}<0.01)$ (SPSS, 20).

\section{RESULTS AND DISCUSSION}

\section{Organoleptic test}

Table 1 showed that as roselle level increased the score of se' $i$ taste also increased $(\mathrm{P}<0.05)$. However, se'i flavour, color and tenderness were not significantly increased $(\mathrm{P}>0.05)$ with increased of roselle level. To some extent, the organoleptic aspects of meat product are influenced by kind of ingredients used during processing. Roselle calyces used in this experiment contained: $0.1 \%$ ascorbate acid, $2.167 \%$ tartaric acid, $2.025 \%$ citrate acid, $1.89 \%$ oxalic acid, $1.76 \%$ succinic acid and $1.66 \%$ malic acid. The presence of the organic acids are responsible for acid taste (Cisse et al. 2009). Taste of se'i samples were 
slightly acid when givien $1-3 \%$ of roselle extract and the acid taste became stronger at the addition of $4-5 \%$ extract. Other experiment reported that addition of roselle calyces extract enhanced sensory attribute (flavour, color and tenderness) of meat processing product "kavurma" (Bozkurt \& Belibagl 2009).

Table 1.Average score flavour, color, taste, tenderness and $\mathrm{pH}$ of se'i treated with Hibiscus sabdariffa calyces extract

\begin{tabular}{lcccccc}
\hline \hline \multirow{2}{*}{ Variables } & \multicolumn{6}{c}{ Treatment } \\
\cline { 2 - 7 } & Control & Roselle 1\% & Roselle 2\% & Roselle 3\% & Roselle 4\% & Roselle 5\% \\
\hline Flavour & $5.00 \pm 0.01$ & $5.00 \pm 0.11$ & $4.55 \pm 0.04$ & $4.25 \pm 0.01$ & $3.75 \pm 0.11$ & $3.05 \pm 0.09$ \\
Color & $3.80 \pm 0.11$ & $4.35 \pm 0.13$ & $4.00 \pm 0.07$ & $4.00 \pm 0.04$ & $4.00 \pm 0.02$ & $4.75 \pm 0.05$ \\
Taste & $3.95 \pm 0.12^{\mathrm{a}}$ & $4.40 \pm 0.10^{\mathrm{b}}$ & $4.60 \pm 0.02^{\mathrm{b}}$ & $4.65 \pm 0.02^{\mathrm{b}}$ & $4.80 \pm 0.01^{\mathrm{c}}$ & $4.95 \pm 0.07^{\mathrm{c}}$ \\
Tenderness & $4.30 \pm 0.10$ & $4.05 \pm 0.03$ & $4.45 \pm 0.07$ & $4.25 \pm 0.07$ & $5.00 \pm 0.07$ & $4.95 \pm 0.01$ \\
$\mathrm{Ph}$ & $5.86 \pm 0.01$ & $5.88 \pm 0.01$ & $6.08 \pm 0.03$ & $5.65 \pm 0.01$ & $5.74 \pm 0.02$ & $5.71 \pm 0.01$ \\
\hline
\end{tabular}

\pm deviation standard. Means within the row followed by different letters were significantly different at $\mathrm{P}<0.05$

Roselle calyces contains anthocyanins which are responsible for the red color (Cisse et al. 2009). Roselle calyces used in this experiment contained $184 \mathrm{ppm}$ anthocyanins. Meat color was mainly determined by the chemical state of the myoglobin molecules. In this experiment, addition of roselle calyces extract did not affect the color of se' $i$ which means that the anthocyanins did not able to change myoglobin molecules. The results provided a good information for se' $i$ industry, since addition of roselle calyces extract did not change the flavour and color but expand the taste. Thus the se' $i$ product could be offered to the consumer with other taste beside conventional taste. Since the taste score of treatment samples were higher than control.

\section{Bacterial characteristic}

Statistical analysis showed that addition of $3-5 \%$ roselle extract was significantly effect the total bacteria number as well as Staphylococcus aureus of se' $i$ samples $(\mathrm{P}<0.05)$ (Table 2). In all se' $i$ samples total plate count were less than $4 \log C F U / g$. It meant that the total plate count met SNI standard for smoked meat (5 log CFU/g). An addition of roselle extract $3-5 \%$ reduced total plate count by $0.03-0.52 \mathrm{CFU}$.

Table 2. The number of total bacteria (cfu), Coliform, E.coli, Salmonella and Staphylococcus aureus (log cfu/g $\pm \mathrm{SD}$ ) of se'i treated with Hibiscus sabdariffa calyces extract

\begin{tabular}{lcccccc}
\hline \hline \multirow{2}{*}{ Variables } & \multicolumn{5}{c}{ Treatment } \\
\cline { 2 - 7 } & Control & $\begin{array}{c}\text { Roselle } \\
1 \%\end{array}$ & $\begin{array}{c}\text { Roselle } \\
2 \%\end{array}$ & $\begin{array}{c}\text { Roselle } \\
3 \%\end{array}$ & Roselle 4\% & Roselle 5\% \\
\hline Total bacteria & $3.38 \pm 0.12^{\mathrm{a}}$ & $3.18 \pm 0.01^{\mathrm{a}}$ & $2.91 \pm 0.04^{\mathrm{a}}$ & $2.86 \pm 0.01^{\mathrm{b}}$ & $2.88 \pm 0.11^{\mathrm{b}}$ & $2.87 \pm 0.10^{\mathrm{b}}$ \\
Coliform (MPN/g) & Negative & Negative & Negative & Negative & Negative & Negative \\
E. coli & Negative & Negative & Negative & Negative & Negative & Negative \\
Salmonella & Negative & Negative & Negative & Negative & Negative & Negative \\
Staphylococcusaureus & $1.82 \pm 0.12^{\mathrm{a}}$ & $1.67 \pm 0.01^{\mathrm{a}}$ & $1.63 \pm 0.04^{\mathrm{a}}$ & $1.10 \pm 0.01^{\mathrm{b}}$ & $1.29 \pm 0.11^{\mathrm{b}}$ & $1.21 \pm 0.10^{\mathrm{b}}$ \\
\hline
\end{tabular}

\pm standard deviation. Means within the row followed by different letters were significantly different $\mathrm{P}<0.05$ 
Staphylococcus aureus is a Gram-positive facultative anaerobic cocci and can grow in food with $\mathrm{pH}$ values ranging from 4 to 9.8 (Medvedova \& Valik 2012). $\mathrm{pH}$ of all se' $i$ samples were similar $(\mathrm{P}>0.05)$, range between 5.65-6.08. Thus it is suitable for Staphylococcus aureus to grow. However, in all se'i samples Staphylococcus aureus, less than $2 \log \mathrm{CFU} / \mathrm{g}$ and this number is below the SNI for smoked meat $2 \mathrm{log} \mathrm{CFU} / \mathrm{g}$ for Staphylococcus aureus (SNI 2009). An addition of roselle extract 3-5\% reduced Staphylococcus aureus 0.05-0.72 CFU.

Coliform, E. coli and Salmonella are gram-negative. Coliform are used as sanitary quality indicator of food and water. The cut-off value for smoked meat is $10 \mathrm{mpn}$ for Coliform, <3/g for E. coli and negative/25g for Salmonella sp. (SNI 2009). In all se’ $i$ samples Coliform, E. coli and Salmonella were not detected, indicating se'i produced in this experiment is save to be consumed.

Hibiscus sabdariffa extract have antimicrobial effect against a wide range of pathogens such as Staphylococcus aureus, Coliform and Escherichia coli (Olaleye 2007), E Coli and Salmonella (Fullerton et al. 2011), Salmonella (Nwaiwu et al. 2012; MoralesCabrera et al. 2013). The ability of Hibiscus sabdariffa extract to reduce total plate count and Staphylococcus aureus indicated that Hibiscus sabdariffa extract contain antimicrobial activity. It was reported that Hibiscus sabdariffa extract contains organic acids and anthocyanins. Beside organic acids, anthocyanins, water-soluble flavonoid pigments also have antimicrobial activity (Morales-Cabrera et al. 2013).

The organic acids could penetrate cell wall of bacteria in the undissociated form which causes the growth of bacteria is limited or death by dissociating and acidifying the cytoplasm of the microorganism (Samelis \& Sofos 2000). Anthocyanins have ability to form a combined complex with bacterial cell walls and also increased hydroxylation which result in increased toxicity (Cowan 1999) thus can kill the bacteria.

\section{CONCLUSION}

Roselle calyces extract can be utilzed in se' $i$ to create a new taste as well as to reduce total plate count and Staphylococcus aureus.

\section{ACKNOWLEDGEMENT}

The authors wish to thank the financial support of Directorate for Higher Education, the Ministry of National Education.

\section{REFERENCES}

Bensink JC, Ford AL, Yates JR. 1973. Properties and performance of a range of commercial vacuum packaging films used for packing chilled beef. Meat Research Report. 4/73. p.1-1.

Bozkurt H, Belibagl KB. 2009. Use of Rosemary and Hibiscus sabdariffa L in production of Kavurma, a cooked meat product. J Sci Food Agric. 89:1168-1173.

Christian KR, Jackson. 2009 JC. Changes in total phenolic and monomeric anthocyanin composition and antioxidant activity of three varieties of sorrel (Hibiscus sabdariffa) during maturity. J Food Comp Anal. 22:663-667.

Chao CY, MC. Yin.2009. Antibacterial effects of Roselle Calyx extracts and protocatechuic acid in ground beef and apple juice. Foodborne Pathog Dis. 6:201-206.

Cisse M, Dornier M, Sakho M, Ndiaye, A, Reynes M, Sock O. 2009. Le bissap (Hibiscus sabdariffa L.): Composition et principales utilisations. Fruits. 64:179-193. 
Cowan MM. 1999. Plant products as antimicrobial agents. Clin Microbial Rev. 12:564-582.

Elliot RP, Clark KH, Lewis H, Lundbeck JC, Olson JR, Simonsen B. 1978. Microorganisms in Food 1. Their Significance and Methods of Enumeration. 2nd ed. Toronto (Canada): University of Toronto Press.

Fullerton M, Khatiwada J, Johnson JU, Davis S, Williams LL. 2011. Determination of antimicrobial activity of sorrel (Hibiscus sabdariffa) on Esherichia coli O157:H7 isolated from food, veterinary, and clinical samples. J Med Food. 14:950-956.

Harrigan WF, McCance ME. 1976. Laboratory methods in food and dairy microbiology. London (UK): Academic Press. p. 452.

Karabacak S, Bozkurt H. 2008. Effects of Urtica dioca and Hibiscus sabdariffa on the quality and safety of sucuk (Turkish dry-fermented sausage). Meat Sci. 78:288-296.

Lin TL, Lin HH, Chen CC, Lin MC, Chou MC, Wang CJ. 2007. Hibiscus sabdariffa extract reduces serum cholesterol in men and women. Nut Res. 27:140-145.

Medvedova A, Valik L. 2012. Staphylococcus aureus: Characterization and quantitative growth description in milk and artisanal raw milk cheese production. In: Eissa AA, editor. Intech. Available from http//www.Intechopen.com/books/structure-and-function-of-foodengineering.

Morales-Cabrera M, Hernandez-Morales J, Leyva-Ruelas G, Salinas-Moreno Y, Soto-Rojas L, Castro-Rosas J. 2013. Influence of variety and extraction solvent on antibacterial activity of roselle (Hibiscus sabdariffa L.) calyces. J Med Plants Res. 7:2319-22.

Nwaiwu NE, Mshelia F, Raufu IA .012. Antimicrobial activities of crude extracts of Moringa Oleifera, Hibiscus $S$ and Hibiscus Esculentus seeds against some enterobacteria. J Appl Phytotechnol Environ Sanit. 1:11-16.

Olaleye M. T. 2007. Cytotoxicity and antibacterial activity of methanolic extract of Hibiscus sabdariffa. J Med Plant Res. 1:9-13.

Samelis J, Sofos J. 2000. Organic acids. In: Roller S, editor. Natural antimicrobials for the minimal processing of foods. CRC, Cambridge UK. Great Abington (UK): Woodhead Publishing Ltd.

SNI. 2009. Maximum Limited of Microbial Contamination of food. SNI: 7388: 2009. Jakarta (Indonesia): Indonesian National Standard. 